\title{
PARENTING DALAM BER-INTERNET SEHAT UNTUK ANAK (Kasus Pornografi)
}

\author{
Syarifah Fatimah
}

\begin{abstract}
Abstrak
Parenting Islam terkait dengan tanggung jawab kedua orang tua terhadap anak, karena anak adalah amanah, sehingga menuntut peran pengasuhan mereka kepadanya. Setiap orang tua dilarang menelantarkan anak. Untuk itu, anak dalam kajian Islam cukup peroleh porsi pembahasan, mulai penyusuan, hak asuh, perwalian, nafkah, sampai pendidikan.

Selain hal itu, pengasuhan anak dalam Islam turut melibatkan dimensi emosional atau kehangatan keluarga, tercermin dalam al-Qur'an, seperti kisah Luqman dan anaknya.
\end{abstract}

Kata Kunci: Akhlak, Pengaruh lingkungan, Perkembangan Psikologis

\section{A. Pendahuluan}

Di zaman ini, anak-anak terlihat akrab dengan internet, baik melalui media gadget maupun komputer. Mereka tidak asing lagi dengan perangkat elektronik tersebut, hingga sebagian mereka terbukti lebih mahir ber-internet dari pada orang tuanya. Hal itu tidak terbatas di kalangan tertentu, melainkan merata di tengah anak orang kaya, ekonomi menengah, sampai keluarga miskin. Pada batas itu, internet telah populer bagi anak-anak.

Pada dasarnya, internet sangat diperlukan masyarakat, karena tuntutan zaman yang terus bergerak ke arah moderenisasi. Di dalam kepentingan itu, pengetahuan tentang internet lalu diperkenalkan di bangku sekolah melalui mata pelajaran Teknologi Informasi dan Komunikasi, terhitung sejak pendidikan tingkat dasar. Zaman menuntut anakanak sekolah mengenal dan mampu memanfaatkan internet atau mereka akan terpinggirkan moderenisasi.

Tuntutan zaman di atas peroleh sambutan positif dari pasar. Mereka segera memproduksi perangkat teknologi untuk internet dengan harga relatif murah dan terjangkau masyarakat, baik jenis gadget atau komputer. Hal itu diikuti dengan murahnya biaya dan mudah akses ke dunia virtual, termasuk layanan yang diberikan warung internet. Produk 
itu diperkenalkan ke tengah masyarakat dengan tampilan menarik dan sederhana dalam pengoperasiannya.

Internet terbukti memberikan banyak manfaat bagi anak, terpenting dunia pengetahuan. Di tengah zaman, hal tersebut harus cukup diperoleh generasi anak-anak, karena mereka akan menghadapi globalitas dunia. Internet diharapkan akan membuka wawasan dan turut serta mencerdaskan anak-anak, tidak terbelakang di tengah pergaulan masyarakat luas. Namun, di saat sama, internet melahirkan suatu tantangan bagi anak-anak, terpenting masalah pornografi. Di dunia virtual itu, pornografi menjadi masalah serius dan sulit terpecahkan. Hal tersebut terkait dengan mudahnya akses dan mengecambahnya pornografi, baik produk local maupun internasional. Pornografi adalah tantangan bagi anak dalam menarik manfaat dari internet.

Pada gilirannya, orang tua sebagai pihak paling bertanggung jawab terhadap pendidikan anak memiliki pekerjaan rumah baru. Mereka harus membimbing anak untuk ber-internet dengan sehat, tidak terjerumus ke dalam dunia pornografi. Di tengah tuntutan zaman, mereka tidak bisa melarang anak meninggalkan internet disebabkan pornografi. Hal itu menjadi pekerjaan rumah bagi orang tua, karena mereka ditantang untuk mengawal anak berinternet sehat.

\section{B. Pornografi di Internet}

Tahun 2008 M. pemerintah telah mengesahkan sebuah Undang-Undang Anti Pornografi dan Pornoaksi/ UU APP. Kebijakan pemerintahan SBY-Kalla ini merupakan langkah strategis guna melindungi anak-anak bangsa Indonesia dari kebrobokan moral. Secara teori, UU APP memberikan mandat kepada pemerintah untuk mengatasi masalah pornografi di masyarakat. Namun, UU APP tidak menjamin bahwa pornografi akan hilang atau mati, karena pornografi memiliki nilai ekonomi, sehingga selalu diproduksi pasar. Pornografi akan terus hadir dan dipertontonkan ke tengah masyarakat, tidak pedulikan UU APP 2008.

Istilah asal pornografi adalah pornographia, terambil dari bahasa Yunani, berarti sebuah gambar tentang wanita tuna susila. Di era Romawi, karya pornografi dijumpai pada tembok, seperti di dinding bangunan lokalisasi. Pada abad ini, pornografi tentu tidak terbatas pada gambar dinding. Seiring perkembangan teknologi, pengertian pornografi dapat meliputi foto dan video. Objek penggambarannya pun tidak terbatas pada wanita tuna susila, tetapi 
meliputi pula foto model, artis, dan siapa pun mereka. Inti pornografi adalah kesenangan libido atau gairah nafsu birahi. Hal itu sebagaimana telah diberikan Kamus Besar Bahasa Indonesia dalam mendefinisikan pornografi. $\mathrm{Di}$ dalam kamus tersebut, pornografi memiliki dua pengertian, 1) penggambaran, baik berupa lukisan atau tulisan, tentang tingkah laku erotis dengan tujuan membangkitkan nafsu birahi, 2) suatu bacaan yang dibuat secara sengaja untuk bangkitkan gairah seks. Pengertian pornografi dalam KBBI telah mengalami perluasan makna, akibat perkembangan pornografi di masyarakat, sehingga tidak terbatas pada gambar.

Satu rahasia umum, internet adalah gudang bagi keberadaan pornografi, karena banyak ditemukan gambar atau video atau tulisan yang diproduksi untuk tujuan membangkitkan gairah seksual atau nafsu birahi. Di Dunia Virtual itu, pornografi telah mengecambah, mulai tampilan seksi, erotis, sampai blue film, terselubung dan terstruktur di dunia tersebut. Internet sebagai ruang bebas tidak akan sepi dari pornografi.

Masalah pornografi di internet semakin sulit teratasi ketika akses terhadap gambar atau video bermuatan atau berisi pornografi dirasa cukup mudah, tidak diperlukan keahlian khusus.
Pornografi dapat ditemukan melalui mesin penelusuran hanya dengan mengetik kata yang memiliki keterkaitan dengan Dunia Seks, baik secara langsung maupun tidak langsung. Satu kata tersebut akan menghubungkan pada suatu tampilan, terus munculkan tampilan lain, dan tampilan seterusnya, tidak terhitung jumlahnya.

Suatu hal tidak begitu mengejutkan ketika Komisi Nasional Anak melansir penelitian terhadap 4500 anak di 12 kota besar di Indonesia dengan hasil bahwa mayoritas dari mereka atau 97 persennya pernah menonton film porno. Selain hal itu, mereka juga mengaku pernah melakukan aktivitas seksual yang tidak sepatutnya bagi anak-anak belum menikah. Hasil sama ditemukan dalam banyak penelitian lain, teraktual adalah penelitian Kemenkominfo bersama UNICEF dan Harvard Univ. Mereka menyimpulkan bahwa banyak anak Indonesia terpapar dengan kontek pornografi di internet. Suatu hal mengejutkan ditunjukan oleh hasil penelitian LSM Jangan Bugil Depan Kamera/JBDK tahun 2007 bahwa 90 persen anak dari respondennya mengakses internet bermuatan pornografi dilangsungkan ketika mereka sedang menyelesaikan tugas sekolah atau belajar kelompok. 
Kasus pornografi terakhir adalah ulah nakal seorang anak di Jakarta yang memposting gambar porno berwajah presiden $\mathrm{RI}$ dan petinggi partai di facebooknya. Sebagai akibatnya, ia dituntut dengan pasal berlapis dengan ancaman hukuman maksimal 12 tahun, karena termasuk pencemaran nama baik. Di dalam kasus itu, tersimpulkan bahwa pornografi mudah ditemukan dan mulai dianggap biasa atau bahan lelucon di kalangan anak-anak, hingga gambar immoral tersebut terpampang di facebook, tidak lagi tersimpan rapat.

Sebuah pengakuan umum di dunia internasional bahwa pornografi adalah suatu hal tercela, melanggar batasan etika, dan terlarang dalam hukum agama. Pornografi tercatat sering menghantarkan kemunculan tindak pidana dan keresahan di tengah masyarakat, terbukti bahwa pelaku kejahatan seksual sering diilhami dari tontonan porno. Selain itu, pornografi menimbulkan efek kecanduan, layaknya mengonsumsi narkoba. Suatu hal tidak mengherankan bahwa pornografi telah didaftarkan sebagai sumber kerusakan bagi moralitas generasi bangsa, termasuk merusak kecerdasan akal, karena efek psikologis yang ditimbulkannya.

\section{Parenting ber-Internet Sehat Untuk Anak}

Konsep parenting diilhami dari ide tentang peran ideal orang tua terhadap anak dalam keluarga, meliputi perhatian, pendampingan, dan bimbingan pada tahapan perkembangan anak, sehingga mereka dapat tumbuh secara optimal. Pada intinya, konsep parenting merujuk pada pengertian pengasuhan orang tua terhadap anak dalam suasana kekeluargaan. Di dalam kontek keluarga itu, Ratna Megawangi memahami parenting sebagai kegiatan belajar dengan kehangatan. Setiap orang tua di dalam konsep parenting diarahkan untuk memberikan yang terbaik dalam pengasuhan anak, demi perkembangan mereka.

Parenting di dalam Islam telah diperkenalkan kepada orang tua. Parenting Islam terkait dengan tanggung jawab kedua orang tua terhadap anak, karena anak adalah amanah, sehingga menuntut peran pengasuhan mereka kepadanya. Setiap orang tua dilarang menelantarkan anak. Untuk itu, anak dalam kajian Islam cukup peroleh porsi pembahasan, mulai penyusuan, hak asuh, perwalian, nafkah, sampai pendidikan. Selain hal itu, pengasuhan anak dalam Islam turut melibatkan dimensi emosional atau kehangatan keluarga, tercermin dalam al-Qur'an, 
seperti kisah Luqman dan anaknya. Pada

batas itu, Islam mengenal konsep tentang parenting.

Di tengah kontek zaman, pornografi tidak dapat dijadikan alasan untuk mengasingkan anak dari internet, karena nilai penting teknologi tersebut bagi anak. Sebagai solusi adalah parenting berinternet untuk anak. Orang tua harus memberikan pendampingan terhadap anak dalam berinternet, sehingga anak terselamatkan dari pornografi. Interaksi anak dengan internet harus peroleh perhatian orang tua, termasuk pengawasan. Seorang anak tidak dapat dibiarkan bebas dan sendirian menjelajahi dunia internet, karena mereka dapat tersandung pornografi.

Suatu langkah awal terpenting bagi orang tua adalah memberikan nasehat kepada anak dan mengingatkannya secara berkelanjutan tentang pornografi. Pada intinya, pornografi harus diposisikan sebagai musuh bagi anak dan masyarakat dalam berinternet, karena pornografi adalah kezaliman dan sangat tercela di sisi-Nya, timbulkan beban dosa. Di dalam nasehat itu, argumentasi rasional dan teologis disampaikan dengan kelembutan, sehingga mudah diterima anak. Kerangka pikir dan kesadaran anak harus memahami nilai negatif pornografi.
Di saat sama, interaksi anak dengan internet harus dapat secara langsung teramati orang tua, sehingga memudahkan pengawasan. Hal itu dapat dilakukan dengan meletakan komputer di ruang terbuka, seperti ruang keluarga. Komputer tidak perlu diletakan di kamar pribadi anak, karena akan memberi ruang dan kesempatan bagi anak untuk bebas menjelajahi isi internet, sehingga rentan terpapar konten pornografi.

Meskipun demikian, pengawasan secara langsung dirasa tidak memadai, karena orang tua tidak mungkin terus menerus di rumah untuk mengamati interaksi anak dengan internet. Pada batas tersebut, suatu pendekatan teknologi diperlukan guna mengantipasi anak terhadap konten pornografi. Di dalam pendekatan itu, pornografi secara sistemis akan diantisipasi oleh suatu program, sehingga tidak mengharuskan kehadiran orang tua untuk mendampingi anak. Pada intinya, melalui pendekatan tersebut, konten pornografi akan terblokir secara otomatis oleh suatu program, tidak lagi dapat terakses.

Pendekatan di atas dapat dilakukan dengan menginstal software anti pornografi ke dalam komputer. Di antaranya adalah software $\mathrm{K} 9$ web protection. Software tersebut dapat diunduh tanpa biaya dan dioperasikan secara mudah, tidak merepotkan 
pengguna. Di bawah ini adalah langkahlangkah teknis untuk memperoleh dan sekaligus menginstal software K9 web protection ke dalam komputer.

1. Buka web browser dan kunjungilah situs K9web protection, beralamat http://www1.K9webprotection.com/getk 9/index. php

2. Lihat gambar di bawah,

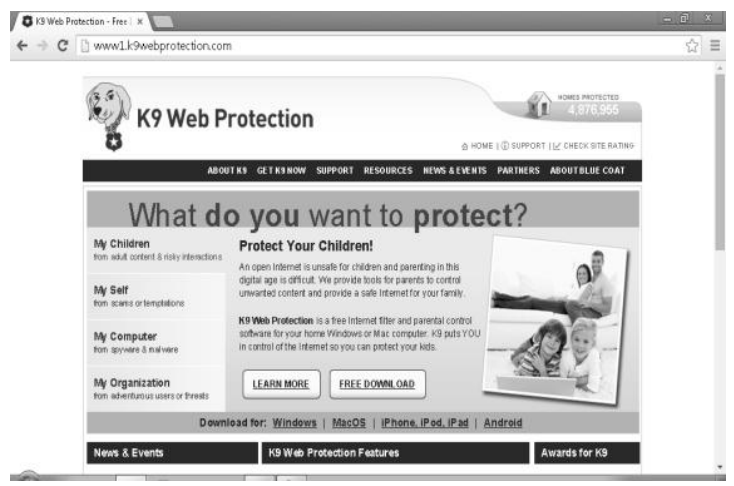

3. Klik kotak yang bertuliskan Free Download.

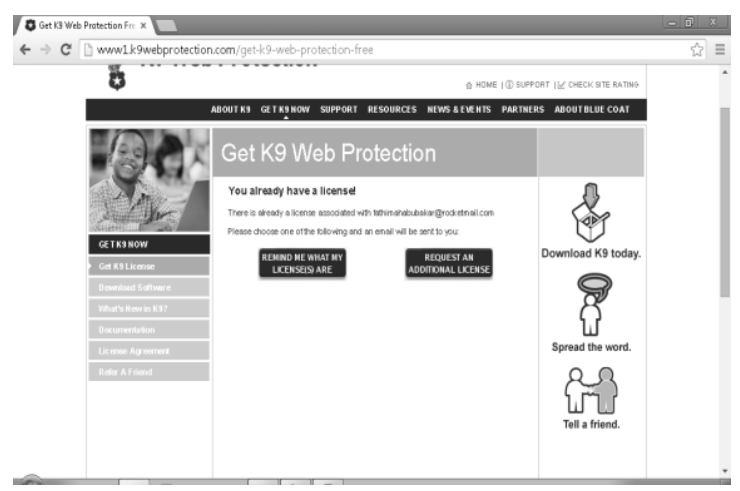

4. Klik kotak yang bertuliskan Request An Additional License. Selanjutnya, program k9web protection dan nomor lisence akan dikirim melalui email.

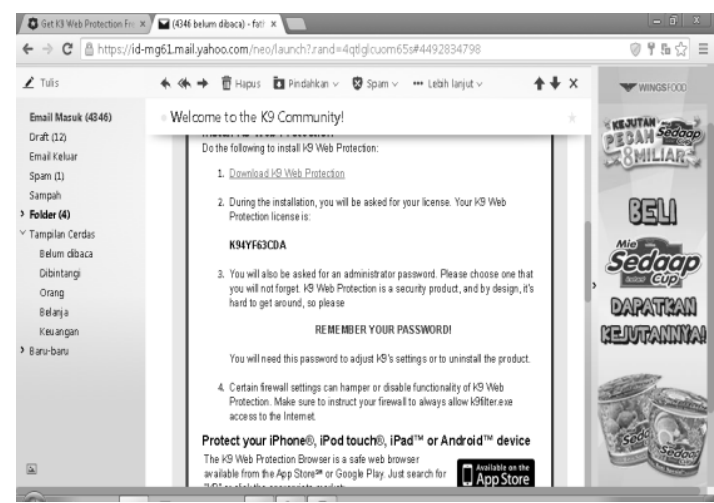

5. Selanjutnya download programnya dan catat nomor licensenya.

6. Tahap selanjutnya lakukan penginstalan terhadap program yang telah didownload.

7. Setelah selesai program sudah dapat digunakan.

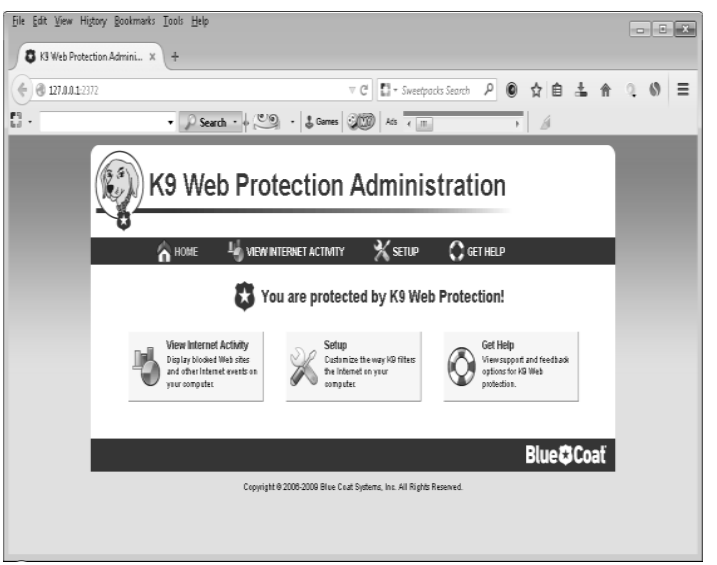


Setelah K9 web protection terinstal, pengaturan program software anti pornografi dapat dilakukan ke dalam komputer. Pada tahap itu, buka blue coat $\mathrm{K} 9$ web protection, lalu atur situssitus tertentu, terkait dengan konten pornografi.

\section{Epilog}

Pada dasarnya, setiap anak terlahir dalam keadaan suci, tidak terbentuk karakter baik atau buruk, kecuali setelah peroleh pengasuhan dari orang tua, karena anak tercipta dari fitrahNya. Oleh sebab itu, orang tua harus mengasuh anak dalam setiap tahapan perkembangannya, karena peran mereka menentukan karakter anak.

Di tengah zaman, muncul kecenderungan orang tua untuk mengabaikan perkembangan anak. Pada saat sama, anak tampak terbiasa tanpa kehadiran orang tua. Internet di dalam kecenderungan itu segera peroleh tempat di hati anak. Hal tersebut tiada masalah, karena nilai penting internet, tetapi anak menjadi rentan bahaya pornografi atau lainnya. Di dalam kontek itu, parenting berinternet sehat untuk anak merupakan suatu solusi. Orang tua diajak peduli terhadap anak dan sekaligus memetik manfaat dari internet.
Pendampingan orang tua terhadap interaksi anak dengan internet akan mengantisipasi banyak bahaya yang dimunculkan di dunia virtual, tidak terbatas pada pornografi. $\mathrm{Di}$ dalam pendampingan tersebut, anak akan lebih terarah dalam memetik manfaat dari internet, mulai kepentingan informasi, komunikasi, sampai hiburan. Hal itu sangat bermanfaat bagi anak di tengah perkembangan dan tuntutan zaman, karena mereka tanpa internet akan terkungkung dalam ketidaktahuan serta tertinggal modernitas zaman.

\section{E. Daftar Pustaka}

\section{Buku}

Megawangi, Ratna. Character Parenting Space. Bandung: Read Publishing House, 2007.

Owen, Madison. How To Protect Your Children Online: Internet Safty Tips For Kids. Bloomington, 2012.

Sanjaya, Ridawan. dkk. Parenting Untuk Pornografi di Internet. Jakarta: Elex Media Kumputindo, 2010.

Soebagijo, Azimah. Pornografi. Jakarta: Gema Insani, 2008.

dkk. Kamus Besar Bahasa Indonesia, ed. III. Jakarta: Balai Pustaka, 2001

\section{Internet}

Republika. co. id.

Nasional. Republika. co. id.

Nasional. News. Viva. co. id.

Okezone. Com. 